\title{
Errata
}

\section{Deinococcus ficus sp. nov., isolated from the rhizosphere of Ficus religiosa $\mathrm{L}$.}

\author{
W.-A. Lai, P. Kämpfer, A. B. Arun, F.-T. Shen, B. Huber, \\ P. D. Rekha and C.-C. Young \\ International Journal of Systematic and Evolutionary Microbiology (2006), 56, part 4, 787-791
}

The type strain of Deinococcus ficus is CCUG 51391, not CCUG 53391 as stated in the paper (E. Falsen, personal communication).

\section{Reclassification of [Flavobacterium] ferrugineum as Terrimonas ferruginea gen. nov., comb. nov., and description of Terrimonas lutea sp. nov., isolated from soil}

\author{
C.-H. Xie and A. Yokota \\ International Journal of Systematic and Evolutionary Microbiology (2006), 56, part 5, 1117-1121
}

On page 1119 (right column, penultimate sentence), the values given for the $\mathrm{G}+\mathrm{C}$ content of the DNA are incorrect. The text should read 'The G+C content of the DNA of strain $\operatorname{DY}^{\mathrm{T}}(47 \cdot 2 \mathrm{~mol} \%)$ and [Flavobacterium] ferrugineum IAM $15098^{\mathrm{T}}(48 \cdot 9 \mathrm{~mol} \%)$ was similar to that of their close relatives.' 